3. Holod, A. P. Safety and security of regional tourism systems: theory, methodology and problems of guarantee, LDUFK, 2017.

4. Denysov, O. Ye. «Theoretical discourse of the entity and the doctrine of economic security in the open economy». The Informer XXI, no. 4, 2017, pp. 9-13.

5. Вовкоva, A. G., Kudrevatykh, S. A., and Ye. L. Pisarevskiy. Safety of tourism, Federal Agency for Tourism, 2014.

6. Zakharov, O. I. and A. V. Snigir «The analysis of the economic security threats of tourism enterprises». Scientific Bulletin of Lviv State University of Internal Affairs. The series is economic, issue 2, 2014, pp. 297-305.

7. Zabashtanskyi, M. M., Zabashtanska, T. V. and A. V. Rogovyi. «Economic security of the state in conditions of the transformation changes of the tourist industry of Ukraine». Problems of Systemic Approach in the Economy, issue 4(1), 2019, pp. 50-55. DOI: https://doi.org/10.32782/2520-2200/2019-47.

8. On tourism: Law of Ukraine of 15.09.1995 № 324/95-VR. Verkhovna Rada of Ukraine. Verkhovna Rada of Ukraine, zakon.rada.gov.ua/laws/show/324/95-вp\#Text. Accessed 14 Oct. 2021.

9. Lazareva, A. P. «Features of economic security of enterprises of tourist sphere». Theoretical and Practical Aspects of Economics and Intellectual Property, issue 1, vol. 2, 2014, pp. 271-276.

10. «UNWTO Launches a call for action for tourism's COVID-19 mitigation and recovery». UNWTO, www.unwto.org/news/unwto-launches-a-call-for-action-for-tourisms-covid-19-mitigation-and-recovery. Accessed 02 Oct. 2021.

11. «UNWTO Launches Comprehensive Tourism Recovery Tracker». UNWTO, www.unwto.org/news/unwto-launches-comprehensive-tourism-recovery-tracker. Accessed 02 Oct. 2021.

12. COVID-19 pandemic and its consequences in the field of tourism in Ukraine (Update to the document «Roadmap for competitive development of tourism in Ukraine»), ntoukraine.org. Accessed 10 Oct. 2021.

13. Zhalilo, Ya. A., Kovalivska, S. V., Fylypenko, A. O., Khymynets, V. V., and A. A. Golovka. Regarding the development of tourism in Ukraine in the conditions of increased epidemic risks: Analytical note of the National Institute for Strategic Studies, 2019.

14. Kyryliuk, I. «Development of tourism in the conditions of the COWID-19 pandemic». Tourism in the 21st Century: Challenges and Responses, 2020, pp. 67-69.

15. Safe Tourism. Go Turkey, safetourismturkiye.com/ru/homepage. Accessed 14 Oct. 2021.

16. «Tourism Statistics, II. Quarter: April - June, 2021». Republic of Turkey Ministry of Culture and Tourism, data.tuik.gov.tr/Bulten/Index?p=Turizm-Istatistikleri-II.-Ceyrek:-Nisan---Haziran,-2021-37441. Accessed 15 Oct. 2021.

17. Chvertko, L. A., and T. A. Demchenko. «Insurance of tourist risks: problems of theory and practice». Economic horizons, no. 1 (4), 2018, pp. 67-75.

18. Chvertko, L. A., Vinnytska, O. A., and T. O. Korniienko. «State and problems of tourist insurance development in Ukraine». The actual problems of regional economy development, issue 16, vol. 1. 2020, pp. 58-67. Doi: 10.15330/apred.1.16.58-67.

УДК 332.1:338

doi: 10.15330/apred.2.17.189-195

Шекета С.Ю. ${ }^{1}$, Казюка Н.П. ${ }^{2}$

\title{
ЕФЕКТИВНИЙ МЕНЕДЖМЕНТ СФЕРИ ТУРИЗМУ ЯК ЗАПОРУКА СТАЛОГО ЕКОНОМІЧНОГО РОЗВИТКУ ОБ'СДНАНИХ ТЕРИТОРІАЛЬНИХ ГРОМАД ПРИКАРПАТТЯ
}

\author{
${ }^{1}$ Івано-Франківський коледж \\ Львівського національного аграрного університету, \\ вул.Юності, 11, м. Івано-Франківськ, \\ 76492, Україна, \\ тел.: 0342554722, \\ e-mail: sheketa-evgenija@ukr.net, \\ ORCID: 0000-0001-7182-9447
}




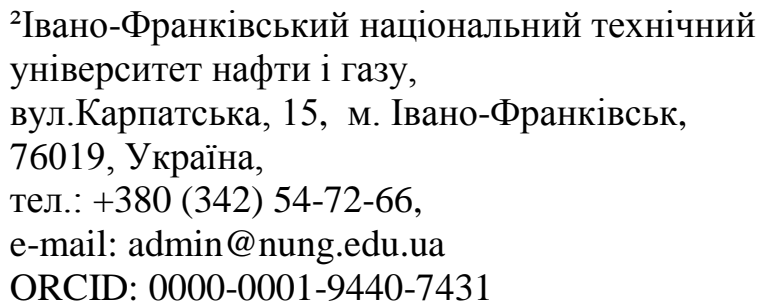

Анотація. У статті досліджено особливості реформування системи місцевого самоврядування на засадах децентралізації влади. Проаналізовано основне нормативно-правове законодавство України, яке регламентує реформу децентралізації влади в Україні. Беззаперечним поступом реформи децентралізації $\epsilon$ добровільне створення самостійних адміністративно-територіальних одиниць - об'єднаних територіальних громад, успіх яких полягає в усвідомленні того, що влада зосереджена в руках кожного, i саме громада визначає пріоритетні напрями свого розвитку та витрачання бюджетних коштів. Проведено SWOTаналіз ринку туристичних послуг Прикарпаття, зокрема визначено слабкі та сильні сторони, можливості для розширення та стримуючі фактори розвитку сфери туристичної індустрії в регіоні.

У статті визначено, що важливим орієнтиром ОТГ повинна стати екологічна спрямованість всіх галузей економіки регіону, оскільки турбота про довкілля є запорукою гармонійного співіснування людини у суспільстві та головною передумовою сталого розвитку та максимального збереження всього живого для майбутніх поколінь.

Встановлено, що ефективний менеджмент і усвідомлення ОТГ того, що індустрія туризму має всі шанси стати однією 3 найприбутковіших галузей економіки регіону, дає можливості подолати негативні тенденції на ринку туристичних послуг, шляхом формування конкретного плану дій через реалізацію державної та регіональної програм у сфері туризму, а також завдяки продуманому інформаційно-маркетинговому супроводу можливо сформувати якісний конкурентоспроможний туристичний продукт на світовому ринку. Цілі сталого розвитку України є орієнтиром для розробки проектів, прогнозів та нормативно-правових актів задля ефективного економічного, екологічного та соціального напрямів сталого розвитку кожної новоствореної ОТГ.

Аналізуючи переваги і недоліки для розвитку туристичної галузі на Прикарпатті увагу ОТГ слід зоріснтувати власне на розвиток інфраструктури регіону: ремонт автомобільних доріг, розширення можливостей авіасполучення, покращення якості, безпеки і комфорту наземного транспорту, з метою безпеки туристів. Важливим орієнтиром ОТГ повинна стати екологічна спрямованість всіх галузей економіки регіону, оскільки турбота про довкілля є запорукою гармонійного співіснування людини у суспільстві та головною передумовою сталого розвитку та максимального збереження всього живого для майбутніх поколінь.

Ключові слова: туризм, об'єднана територіальна громада, сталий економічний розвиток, реформа децентралізації, місцеве самоврядування.

\section{Sheketa E. Yu. ${ }^{1}$, Kaziuka N.P. ${ }^{2}$ EFFECTIVE TOURISM MANAGEMENT AS A GUARANTEE OF SUSTAINABLE ECONOMIC DEVELOPMENT OF THE UNITED TERRITORIAL COMMUNITIES OF PRICARPATHIA}

${ }^{1}$ Ivano-Frankivsk College of Lviv National

Agrarian University,

Yunosti str., 11, Ivano-Frankivsk,

76492, Ukraine,

tel.: 0342554722,

e-mail: sheketa-evgenija@ukr.net

ORCID: 0000-0001-7182-9447 
${ }^{2}$ Ivano-Frankivsk National Technical University of Oil and Gas,

15, Karpatska str., Ivano-Frankivsk, 76019, Ukraine, tel.: +380 (342) 54-72-66, e-mail: admin@nung.edu.ua

ORCID: 0000-0001-9440-7431

\begin{abstract}
The article examines the features of reforming the system of local self-government of decentralization of power. The basic normative-legal legislation of Ukraine, which regulates the reform of decentralization is analyzed. An indisputable step in decentralization reform is the voluntary creation of independent administrative-territorial units - united territorial communities, whose success lies in the realization that power is concentrated in the hands of everyone, and it is the community that determines the priorities of its development and budget spending. A SWOT-analysis of the tourist services market in Prykarpathia region is carried out; in particular, weaknesses and strengths, opportunities for expansion and restraining factors of development of the sphere of tourist industry in the region were identified.

The article stipulates that the ecological orientation of all sectors of the region's economy should become an important reference point of UTC, as care for the environment is the key to harmonious human coexistence in society and the main prerequisite for sustainable development and maximum preservation of all living things for future generations.

The article establishes that effective management and awareness of UTC that the tourism industry has every chance to become one of the most profitable sectors of the region, allows overcoming the negative trends in the tourism market by forming a specific action plan through the implementation of state and regional programs in tourism. Thanks to the thought-over information and marketing support, it is possible to form a qualitative competitive tourist product in the world market. The goals of sustainable development of Ukraine are a reference point for the development of projects, forecasts and regulations for the effective economic, environmental and social areas of sustainable development of each newly created UTC.

The analysis the advantages and disadvantages for the development of the tourism industry in Prykarpattia shows, that UTC should focus on the development of infrastructure in the region: repair of roads, expanding air travel, improving the quality, safety and comfort of land transport, for the safety of tourists. An important guideline of UTC should be the ecological orientation of all sectors of the region's economy, such as care for the environment is the key to harmonious human coexistence in society and the main prerequisite for sustainable development and maximum preservation of all living things for future generations.
\end{abstract}

Key words: tourism, united territorial community, sustainable economic development, decentralization reform, local self-government.

Вступ. Процес децентралізації влади в Україні розпочався в 2014 році, і полягає передусім у реформуванні системи місцевого самоврядування, а об'єднана територіальна громада (далі ОТГ) постала у фокусі наукових, суспільних та політичних дискусій. Відповідно до прийнятого Закону України від 16 квітня 2020 року № 562-IX "Про внесення змін до деяких законів України щодо визначення територій та адміністративних центрів територіальних громад” [1], в Україні відбувся новий адміністративно-територіальний розподіл, а згідно Закону України від 5 лютого 2015 року № 157-VIII “Про добровільне об'єднання територіальних громад” [2] визначено адміністративні центри та затверджено території об'єднаних територіальних громад. У 2020 році відбулися вибори до новостворених ОТГ і зараз перед кожною такою громадою постало питання формування траєкторії індивідуального організаційноуправлінського механізму на основі сталого економічного розвитку. 
Питанням децентралізації, обумовленим реформою місцевого самоврядування, присвячено наукові праці таких дослідників: Батанов О., Барановська Т., Гладій В., Колодій А., Корнієнко М., Любченко П., Шевчук С. Значний внесок у дослідження теорії менеджменту сфери туризму зробили ряд вітчизняних та зарубіжних вчених, зокрема: Бойко М., Верланов Ю., Герасименко В., Долішній М., Каспар К., Кріппендорф Й., Мельниченко С., Нортон Д., Роскладка Н., Ткаченко Т. та інші, які у своїх працях аналізували особливості фінансової та управлінської діяльності туристичних бізнес-структур, виокремлювали основні підходи підвищення ефективності менеджменту сфери туризму тощо. Серед науковців Прикарпаття у сфері дослідження пріоритетних напрямів туристичної політики регіону слід виокремити Архипову Л., Великочий В., Гуменюк В.

Постановка завдання. Головне, що випливає з вищенаведеного, це формування кожною ОТГ вектору руху, тобто виокремлення окремих завдань та пріоритетних сфер розвитку регіону, на основі аналізу його потенціалу, ресурсів і можливостей, з метою забезпечення принципів сталого економічного розвитку, що і покладено в основу дослідження. Саме ці положення є основною метою написання даної статті.

Основними методами дослідження, які були використані у статті, є методи індукції, дедукції, абстрагування, аналізу та синтезу.

Результати. Процес реформування місцевого самоврядування, обумовлений децентралізацією влади в Україні, розпочався у 2014 році з прийняття Концепції реформування місцевого самоврядування та територіальної організації влади в Україні [3]. Хоча задовго до цього, у липні 1997 року Україною було ратифіковано Європейську хартію місцевого самоврядування $[4,5]$. Цілі сталого розвитку України на період до 2030 року зазначені в указі Президента України від 30 вересня 2019 року № 722/2019 [6] і є орієнтиром для розробки проектів, прогнозів та нормативно-правових актів задля ефективного економічного, екологічного та соціального напрямів сталого розвитку кожної новоствореної ОТГ.

Успіх кожної громади полягає в усвідомленні того, що влада перебуває в їх руках, в руках кожного зокрема. В умовах децентралізації влади не хтось за когось вирішує, а кожна окрема громада визначає пріоритети свого розвитку, тобто куди і як витрачати бюджетні кошти. Рушійною силою прогресу у цьому напрямі $є$ креативність і творчий підхід ОТГ, грамотне позиціонування себе країні і світу, що більшою мірою залежить від мотивації та пошуку нових інноваційних ідей та напрямів свого розвитку. Реалізація таких ідей змінює громаду, створює іiі унікальний образ, сприяє впровадженню конкурентоспроможних проектів, нових стратегій, започатковує партнерські стосунки [7, с. 4]. Повноваження передаються державою органам місцевого самоврядування, що діють на тому рівні адміністративно-територіального устрою враховуючи кадровий, фінансовий, інфраструктурний та ресурсний потенціали регіону. Згідно Бюджетного кодексу України [8] та Закону України про державний бюджет на відповідний рік [9] всі місцеві податки та частина загальнодержавних податків залишаються у розпорядженні ОТГ та є джерелом її власних фінансових ресурсів. 
SWOT-аналіз ринку туристичних послуг Прикарпаття*

Таблиия 1

SWOT-analysis of the tourist services market of Prikarpathia*

Переваги:
- потужний природно-ресурсний та
рекреаційний потенціал регіону;
- наявність різноманітних культурно-
історичних пам’яток;
- зручне географічн розташування
регіону в центрі Свропи;
- безвізовий режим з країнами Європи;
- приваблива цінова політика для
іноземців на туристичні послуги;
- широкий спектр туристичних послуг;
- високий освітньо-культурний рівень
населення регіону (в тому числі
персоналу сфери туризму);
- позитивний імідж туристичної індустрії
регіону.

Можсливості:

- залучення всіх інструментів маркетингу при позиціонуванні регіону на регіональних та міждержавних ринках туристичних послуг;

- упровадження стимулів та мотивації для ОТГ просувати туристичні послуги регіону;

- розробка і впровадження різноманітних інформаційних ресурсів і порталів при наданні та просуванні туристичних послуг;

- креативний супровід туристичної індустрії (акцент на унікальні автентичні регіональні особливості: сувеніри, вишиваний одяг, елементи побуту, тощо).

- екоорієнтація ОТГ: вирощування органічних продуктів харчування та турбота про довкілля як основа розвитку сільського “зеленого" туризму, агро- та екотуризму.

\section{Недоліки:}

- нестабільна політична ситуація в країні (військовий конфлікт на Сході України);

- слабо розвинена інфраструктура регіону: погана якість автомобільних доріг, незначні можливості авіасполучення;

- недосконале нормативно-правове законодавство у сфері регулювання туристичних послуг;

- неефективна маркетингова політика регіону при просуванні туристичних продуктів на державному та світовому ринках.

\section{Загрози:}

- відсутність впровадження новітніх CRM - систем у сфері туризму;

- брак високовмотивованих кадрів, орієнтованих на постійне навчання впродовж життя, здатних щоразу опановувати новітні інформаційні ресурси та діджитал технології у сфері туризму;

- відсутність ефективної державної та регіональної програми просування туристичних послуг;

- відсутність комплексних наукових та статистичних досліджень туристичних потоків у регіоні та їх вплив на формування дохідної частини бюджету; - відсутність стратегії та продуманої інформаційно-маркетингової підтримки індустрії туризму у країні та світі;

- низький рівень життя населення країни, як блокуючий фактор розвитку внутрішнього туризму

\footnotetext{
Розроблено авторами.
}

В рамках проведення реформи децентралізації в Івано-Франківській області створено 62 ОТГ, які об’єднані в 6 районів з кількістю населення 1368 тис. чоловік. Цей регіон має унікальні природні ресурси i масштабний потенціал для розвитку туристичної індустрії, а саме: гірськолижний туризм, піший туризм із унікальними туристичними маршрутами, курортно-рекреаційний туризм, сільський (зелений) 
туризм, агро- та екотуризм. Аналізуючи переваги і недоліки для розвитку туристичної галузі на Прикарпатті (див. табл. 1) доцільно відзначити, що фокус уваги ОТГ слід зорієнтувати власне на розвиток інфраструктури регіону: ремонт автомобільних доріг, розширення можливостей авіасполучення, покращення якості, безпеки і комфорту наземного транспорту, з метою безпеки туристів. Важливим орієнтиром ОТГ повинна стати екологічна спрямованість всіх галузей економіки регіону, оскільки турбота про довкілля $є$ запорукою гармонійного співіснування людини у суспільстві та головною передумовою сталого розвитку та максимального збереження всього живого для майбутніх поколінь. Ефективний менеджмент і усвідомлення ОТГ того, що індустрія туризму має всі шанси стати однією 3 найприбутковіших галузей економіки регіону, дає можливості подолати негативні тенденції на ринку туристичних послуг, шляхом формування конкретного плану дій через реалізацію державної та регіональної програм у сфері туризму, а також завдяки продуманому інформаційно-маркетинговому супроводу можливо сформувати якісний конкурентоспроможний туристичний продукт на світовому ринку.

Висновки. Таким чином, у результаті здійсненого дослідження можна констатувати, що формування кожною ОТГ напрямів руху, визначення певних цілей та пріоритетів розвитку доцільно реалізовувати на основі оцінки його ресурсів, загального потенціалу та перспективних можливостей.

Результатом реформування місцевого самоврядування є процес децентралізації влади 3 добровільним створенням нових територіальних одиниць - об'єднаних територіальних громад, яким делеговано право самостійного прийняття управлінських рішень щодо формування та використання власних фінансових ресурсів. Новоутворені ОТГ Прикарпаття володіють масштабними природніми ресурсами i значним потенціалом для розвитку туристичної індустрії на своїх територіях. Саме ефективний менеджмент і креативний підхід у просуванні туристичних брендів регіону сприятиме впровадженню конкурентоспроможних проектів. Орієнтація державних і регіональних програм розвитку у сфері туризму допоможуть кожній ОТГ сформувати свій вектор руху у цьому напрямі, а усвідомлення і впровадження місцевою владою ціннісних орієнтирів екологічної спрямованості всіх галузей економіки дають всі шанси регіону стати лідером екотуризму на засадах сталого економічного розвитку.

1. Про внесення змін до деяких законів України щодо визначення територій та адміністративних центрів територіальних громад: Закон України від 16 квітня 2020 року № 562-IX. URL: https://zakon.rada.gov.ua/laws/show/562-20\#Техt (дата звернення: 28.02.2021).

2. Про добровільне об’єднання територіальних громад: Закон України від 5 лютого 2015 року № 157VIII. URL: https://zakon.rada.gov.ua/laws/show/157-19\#Text (дата звернення: 28.02.2021).

3. Концепція реформування місцевого самоврядування та територіальної організації влади в Україні: Розпорядження Кабінету Міністрів України від 1 квітня 2014 року № 333-p. URL: https://zakon.rada.gov.ua/laws/show/333-2014-\%D1\%80\#Text (дата звернення: 28.02.2021).

4. Свропейська хартія місцевого самоврядування. Рада Європи, м. Страсбург. Міжнародний документ від 15 жовтня 1985 року. URL: https://zakon.rada.gov.ua/laws/show/994_036\#Техt (дата звернення: 28.02.2021).

5. Про ратифікацію Європейської хартії місцевого самоврядування: Закон України від 15 липня 1997 року № 452/97-BP. URL: https://zakon.rada.gov.ua/laws/show/452/97-\%D0\%B2\%D1\%80\#Tеxt (дата звернення: 28.02.2021).

6. Про Цілі сталого розвитку України на період до 2030 року: указ Президента України від 30 вересня 2019 року № 722/2019. URL: https://zakon.rada.gov.ua/laws/show/722/2019\#Tехt (дата звернення: 28.02.2021).

7. Успішна територіальна громада: будуємо разом / Бриль М., Врублевський О., Данчева О., Сеїтосманов А., Чубаров Е. Харків: Видавничий будинок Фактор, 2018. 128 c. URL: https://despro.org.ua/library/publication/UspishnaTerytorialnaHromada2018.pdf $\quad$ (дата звернення: 28.02.2021). 
8. Бюджетний кодекс України: Закон від 08 липня 2010 року № 2456-VI, зі змінами та доповненнями. URL: https://zakon.rada.gov.ua/laws/show/2456-17\#Text (дата звернення: 28.02.2021).

9. Про державний бюджет України на 2021 рік: Закон України від 15 грудня 2020 року № 1082-IX. URL: https://zakon.rada.gov.ua/laws/show/1082-20\#Text (дата звернення: 28.02.2021).

\title{
References
}

1. On Amendments to Certain Laws of Ukraine Concerning the Definition of Territories and Administrative Centers of Territorial Communities: Law of Ukraine of April 16, 2020 № 562-IX. Verkhovna Rada of Ukraine, zakon.rada.gov.ua/laws/show/562-20\#Text. Accessed 28 Feb.2021.

2. On voluntary association of territorial communities: Law of Ukraine of February 5, 2015 № 157-VIII. Verkhovna Rada of Ukraine, zakon.rada.gov.ua/laws/show/157-19\#Text. Accessed 28 Feb.2021.

3. The concept of reforming local self-government and territorial organization of power in Ukraine: Order of the Cabinet of Ministers of Ukraine of April 1, 2014 № 333-r. Verkhovna Rada of Ukraine, zakon.rada.gov.ua/laws/show/333-2014-\%D1\%80\#Text. Accessed 28 Feb.2021.

4. European Charter of Local Self-Government. Council of Europe, Strasbourg. International document dated October 15, 1985. Verkhovna Rada of Ukraine, zakon.rada.gov.ua/laws/show/994_036\#Text. Accessed 28 Feb.2021.

5. On ratification of the European Charter of Local Self-Government: Law of Ukraine of 15 July 1997 № 452/97-BP. Verkhovna Rada of Ukraine, zakon.rada.gov.ua/laws/show/452/97-\%D0\%B2\%D1\%80\#Text. Accessed 28 Feb.2021.

6. On the Goals of Sustainable Development of Ukraine for the period up to 2030: Decree of the President of Ukraine of September 30, 2019 № 722/2019. Verkhovna Rada of Ukraine, zakon.rada.gov.ua/laws/show/722/2019\#Text. Accessed 28 Feb.2021.

7. Bryl, M., Vrublevsky, O., Dancheva, O., Seitosmanov, A., and E.Chubarov Successful territorial community: building together. Kharkiv, Factor Publishing House, 2018. DESPRO, despro.org.ua/library/publication/UspishnaTerytorialnaHromada2018.pdf. Accessed 28 Feb.2021.

8. Budget Code of Ukraine: Law of July 8, 2010 № 2456-VI, as amended. Verkhovna Rada of Ukraine, zakon.rada.gov.ua/laws/show/2456-17\#Text. Accessed 28 Feb.2021.

9. On the state budget of Ukraine for 2021: Law of Ukraine of December 15, 2020 № 1082-IX. Verkhovna Rada of Ukraine, zakon.rada.gov.ua/laws/show/1082-20\#Text. Accessed 28 Feb.2021.

\section{УДК 338.48}

doi: 10.15330/apred.2.17.195-203

\section{СТРАТЕГІЇ ОНЛАЙН-ПРОДАЖУ ГОТЕЛЬНОГО ПРОДУКТУ}

Мендела I.Я.

\author{
Прикарпатський національний університет \\ ім.В.Стефаника, \\ Міністерство освіти і науки України, \\ факультет туризму, \\ кафедра готельно-ресторанної та курортної справи, \\ вул. Галицька, 201б, м. Івано-Франківськ, \\ 76008, Україна, \\ тел.: 778801, \\ e-mail: mendela_i@ukr.net, \\ ORCID ID: 0000-0002-7282-643X
}

\footnotetext{
Анотація. Підтримання конкурентоспроможності готельного бізнесу неможливе без впровадження та розвитку онлайн-продаж готельних послуг, а також вирішення проблем, що виникають внаслідок здійснення цих операцій.

Метою дослідження $є$ вивчення ринку інтернет-технологій, які функціонують в готельному бізнесі. За допомогою аналізу описано онлайн-сервіси для продажу готельних послуг, моделювання показано роботу мобільного додатку для продажу онлайн-послуг готелю, за допомогою методу прогнозування описано можливі результати застосування цифрового маркетингу в роботі готелю.
} 